\title{
INEQUALITY AND INFANT AND CHILDHOOD MORTALITY IN THE UNITED STATES IN THE TWENTIETH CENTURY
}

\author{
Michael R. Haines \\ Working Paper 16133 \\ http://www.nber.org/papers/w16133 \\ NATIONAL BUREAU OF ECONOMIC RESEARCH \\ 1050 Massachusetts Avenue \\ Cambridge, MA 02138 \\ June 2010
}

The views expressed herein are those of the author and do not necessarily reflect the views of the National Bureau of Economic Research.

NBER working papers are circulated for discussion and comment purposes. They have not been peerreviewed or been subject to the review by the NBER Board of Directors that accompanies official NBER publications.

(C) 2010 by Michael R. Haines. All rights reserved. Short sections of text, not to exceed two paragraphs, may be quoted without explicit permission provided that full credit, including $\odot$ notice, is given to the source. 
Inequality and Infant and Childhood Mortality in the United States in the Twentieth Century Michael R. Haines

NBER Working Paper No. 16133

June 2010

JEL No. I1,N12

\begin{abstract}
$\underline{\text { ABSTRACT }}$
This paper deals with the issue of using infant and childhood mortality as an indicator of inequality. The case is that of the United States in the 20th century. Using microdata from the 1900 and 1910 Integrated Public Use Microsamples (IPUMS), published data from the Birth Registration Area in the 1920s, results from a number of surveys, and the Linked Birth \& Infant Death Files from the National Center for Health Statistics for 1991, infant and child mortality can be related to such other variables as occupation of father or mother, education of father or mother, family income, race, ethnicity, and residence. The evidence shows that, although there have been large absolute reductions in the level $\mathbb{R}$ infant and child mortality rates and also a reduction in the absolute levels of differences across socioeconomic groups, relative inequality has not diminished over the 20th century.
\end{abstract}

Michael R. Haines

Department of Economics, 217 Persson Hall

Colgate University

13 Oak Drive

Hamilton, NY 13346

and NBER

MHAINES@MAIL.COLGATE.EDU 
INTRODUCTION

The issue of inequality has been, and remains, a central concern for social science and public policy. For instance, despite dramatic increases in income, wealth, and standard of living in developed, industrial nations, segments of the populations in those nations have remained disadvantaged. In the United States, the real consumption wage remained relatively stagnant from the mid 1980s to the mid 1990s. Real median family and individual incomes were stagnant or declining over that period [Council of Economic Advisers, 1996, pp. 61, 314]. Tha share of money income going to the top 5\% of households increased from 15.8\% in 180 to $21.4 \%$ in 1998 . [Carter, et al., 2006, Table Be 1-18]. Some nations and regions in the developing world have stagnated or even experienced deterioration of living standards [United Nations, 1999, pp. 37-41]. In the study of inequality and distribution, the focus has often been on inputs, such as income, although the historical statistics on income distribution are considered quite deficient [Kuznets, 1966, ch. 4]. Nevertheless, it is often better to focus rather on outcomes, such as health and mortality. This is the essence of the World Bank's Basic Needs Indicators [Hicks and Streeten, 1975], which include such things as nutrition, health, housing, sanitation, and education. ${ }^{1}$ The expectation of life at birth and the infant mortality rate are among the measures used. Some of the more frequently used development indicators include similar outcome variables, notably demographic ones. The Physical Quality of Life Index [Overseas Development Council, 1979] uses the expectation of life at age one, the infant mortality rate, and the literacy rate. The Human Development Index of the United Nations Development Program [United Nations, 1994, ch. 5] includes the expectation of life at birth (which is heavily influenced by the infant mortality rate), adult literacy, mean years of schooling, and real GDP per capita adjusted for purchasing power parity.

The infant mortality rate has frequently been used as a social indicator. Sor, for example, Sir Arthur Newsholme in Britain wrote in 1910: "Infant Mortality is the most sensitive index we possess of social welfare and of sanitary administration, especially under urban conditions" [cited in Titmuss, 1943, p. 12]. The Physical Quality of Life Index uses the IMR explicitly. In the United States, early efforts by the Children's Bureau focused on collection of demographic statistics and studies of

\footnotetext{
1 Some of these features of basic needs are both inputs and intermediate outputs. Education and health are goods in and of themselves, but also increase labor productivity.
} 
infant mortality [Lindenmeyer, 1997, ch. 3; Woodbury, 1926; Bremner, 1971, pp. 958965; Meckel, 1990, ch. 4].

In this paper an effort is made to trace trends in inequality over the $20^{\text {th }}$ century in the United States using infant and childhood mortality as a social indicator of an important outcome. ${ }^{2}$ At various points, appeal is made to social class. This complex concept can be made measurable in a variety of ways: by occupation, by income, by wealth and property, by education (human capital), by residence. Some use is made of all these dimensions, although, at basis, the issue is really one of "life chances". [Weber, 1963 [1920]; Dahrendorf, 1979].

TRENDS IN INEQUALITY IN INFANT MORTALITY IN THE UNITED STATES: the $1890 \mathrm{~S}$ to the $1990 \mathrm{~s}$

The starting point for this study is the United States Census of 1900, which asked questions on the number of children ever born, the number of children surviving, and the duration of current marriage of married, adult women. ${ }^{3}$ Nothing was ever tabulated from those questions, but a public use microsample (of about 100,000 individuals) has been created which permits use of these data. This census has been used by Preston and Haines [Preston and Haines, 1991; Haines and Preston, 1997] to make estimates of childhood mortality. The methodology of indirect estimation is described in detail elsewhere [United Nations, 1983, ch. III; Preston and Haines, 1991, ch. 2; Haines and Preston, 1997]. The same techniques were also applied to the microsample of the 1910 United States Census (of about 366,000 individuals) which also asked the same questions [Preston, Ewbank, and Hereward, 1994; Haines and Preston, 1997]. The fundamental intuition is that the proportion of children dead for a certain age group or marriage duration group of women can be adjusted with a model to yield a life table parameter, namely $\mathrm{q}(\mathrm{x})$, which is the proportion of children dying before reaching exact age " $x$ ". The " $x$ " depends on the age or duration group of women. Each of these estimated $\mathrm{q}(\mathrm{x})$ values can also be dated to a specific point in time prior to the census date. A great advantage of this method is that it allows tabulation of mortality differentials by characteristics of the parents - in this case occupation of father.

The starting point is the federal censuses of 1900 and 1910 (Tables 1 and 2). Child mortality is summarized in these tables as a mortality index. The index is

\footnotetext{
2 For an overview of the history of inequality and distribution in the United States, see Williamson and Lindert [1980].

3 These questions had been asked before in 1890, but nothing was tabulated using these questions and the manuscripts of that census were largely destroyed.
} 
approximately 1.0 for all women in the sample at each date. An index value below one indicates lower than average childhood mortality of that group of women, while an index value above one points to the opposite. In both tables the sample is restricted to women aged 14 to 49 who were married 0-24 years, once married with husband present, and for whom children ever born and children surviving were known. ${ }^{4}$ This resulted in a total sample of 12,624 women with 23,073 children ever born in 1900 and 39,305 women with 61,636 children ever born in 1910. The mortality index itself is calculated at the ratio of actual children dead (computed as the difference of children ever born and children surviving) to expected children dead for each group of women. Expected children dead is calculated by multiplying the children ever born in each marriage duration group (0-4 years, 5-9 years,..,20-24 years) by the expected proportion dead for that marriage duration group using the Trussell/United Nations model and the Coale and Demeny [1966] Model West life tables [see United Nations, 1983, ch. III; Haines and Preston, 1997, Table A1]. For 1900, the West Model life table chosen for the standard was level 13 for both sexes combined, and for 1910 it was level 13.5. The results for 1900 apply approximately to the year 1895 and those for 1910 to approximately to the year 1904 .

Husband's occupation is used as an indicator of social status for the 1900 and 1910 census estimates. The detailed occupations were organized into the tenfold classification of the 1950 United States Census. ${ }^{5}$ For the black population, relatively few cases were found in the higher socioeconomic status groups, so that Professional and Technical; Managers, Officials, and Proprietors; Clerical; and Sales were combined together. In general, the least well of groups (usually non-farm laborers) had childhood mortality 40-100\% higher than the most favored groups. The baseline in the last three columns was set at 100 for the Professional and Technical group, but farmers (agricultural except laborers), clerical and sales often did better in 1900. This was usually not true in 1910. Inequality across occupational groups in childhood mortality was mostly great among foreign-born whites and among blacks than among native-born whites. A rural-urban breakdown is also provided in Tables 1 and 2 . In 1900, inequality was usually worse in urban areas than in rural places, but the effect was not pronounced. This had changed a bit by 1910 - urban areas were still worse off

\footnotetext{
4 The imputed cases of children ever born and children surviving in the IPUMS samples were not used. They produced erratic results.

5 The IPUMS provides a mapping between the occupations in 1900 and 1910 and the 1950 census stratification scheme.
} 
for foreign-born whites and blacks but not for native-white women.

The next point in the twentieth century for which national level data are available is the 1920s. During that period, the United states Bureau of the Census, which had the responsibility for collecting vital statistics from state and local governments and for published them, was tabulating statistics on births, children ever born, children surviving, and number of women by age of woman and detailed occupation of husband for the Birth Registration Area. The entire nation was not covered by vital statistics reporting until 1933. Prior to that, a Death Registration Area (1900-1932) and a Birth Registration Area (1915-1932) were gradually built up to the national system by incorporating only those states and cities which had vital statistics collection which met certain minimum standards. These birth data are reported for 1924 in Table 3 and for 1929 in Table 4 [U.S. Bureau of the Census, 1926 , Table 10; 1932, Table 10].6 In 1924, the Birth Registration area covered about 76\% of the American population. The coverage was at about 95\% in 1929 [Carter, et al., 2006, Table Ab1-37]. The detailed occupations of husband from the birth and infant mortality statistics volumes were re-aggregated into the same 1950 U.S. Census groupings as used for 1900 and 1910. While the published tables did not cover all occupations of husband, they did encompass 90.9\% of all registered births in 1924 and 91.6\% in 1929. The Trussell/United Nations age model of indirect child mortality estimation was applied to calculate $\mathrm{q}(2)$ (the probability of dying before reaching exact age 2) based on women aged 20-24 years and q(5) (the probability of dying before reaching exact age 5) based on women aged 30-34 years [United Nations, 1983, pp. 7681]. The estimates for 1924 apply to about the year 1919 for $q(2)$ and to approximately 1916-1917 for q(5). Similarly, the dating was approximately 1924 for the $q(2)$ calculated from the 1929 data and about 1921-1922 for the q(5) from the 1929 information. No breakdown by nativity, race, or residence was available.

Looking at the results in Tables 3 and 4, inequality in the 1920s was, if anything, worse than it had been in 1900 and 1910. Interestingly, farmers and agricultural laborers no longer enjoyed a favorable situation with respect to child mortality. The health advantage of rural residence was disappearing as the urban mortality penalty was being eliminated [see Haines, 1999]. By the 1920s many cities were healthier than surrounding rural areas, especially because of more rapid and extensive improvements in urban water supplies, sewerage disposal, food and milk

6 These data were first utilized by Ewbank and Preston [1990]. 
protection, and other aspects of public health. The 1920s were also a decade of worsening income and wealth distribution in general [Williamson and Lindert, 1980, pp. 75-82]. The mortality gradients in the 1920s were now more regular with Professional and Technical have the lowest child mortality, passing up through Clerical, Sales, and Managers-Officials-Proprietors and finally up through skilled manual workers, operatives, and both farm and non-farm laborers. By 1929, non-farm laborers now had a q(5) level two to three times as high as that for women with husbands having professional or technical occupations.

During that same era, the Children's Bureau came into existence (1912) [Lindenmeyer, 1997]. One of its first efforts was to undertake studies of infant mortality. Over the period 1912 to 1915, eight cities were studied (Johnstown, PA; Manchester, NH; New Bedford, MA; Waterbury, CT; Akron, OH; Saginaw, MI; Brockton, MA; and Baltimore, MD) and samples were taken totaling 22,967 live births and 2,555 infant deaths. The infant deaths were matched to the birth certificates, and the birth certificates were traced to the families who were, in turn, interviewed. The results were summarized later by Woodbury [1926]. These were extraordinary studies in that elicited information on breast feeding, income, and birth intervals, as well as the standard demographic information (e.g., age, race, nativity, family relationships). Selected results are given in Table 5. There was a clear gradient from low to high incomes with the highest infant mortality rate occurring in families with the husband reporting no earnings. The penalty for having a male family head without work was tragic - it raised the infant mortality rate by $357 \%$ over the highest income group (\$1,250 and over). The risk of having a child death was decreased by $26 \%$ by just moving into the lowest income category (\$450 and below). This accords with the finding of Preston and Haines [1991, chs. 3 and 4, especially tables 3.1 and 4.1 ] for the 1900 census that unemployment of the husband had a consistent and considerable negative impact on child survival. If the husband reported some unemployment in the year prior to the census, it raised the mortality index by about 26\% (and by about 16\% when controlling for a number of other variables). In the 1912-15 surveys, at any given income level, native white women usually did better than foreign-born white women, but not consistently so and not by too much. Tabulations by income show that both blacks and foreign-born whites had higher infant mortality rates because they were, on average, poorer than native whites. Nevertheless, the lower panels of Table 5 show that breast feeding could make a difference for some groups. Ethnic groups with a higher incidence of breast feeding (e.g., Italian, Polish, and Jewish women) 
but with a higher proportion of lower income families (percent with incomes below $\$ 650)$ did better in terms of child survival than did similar groups with a low incidence of breast feeding (e.g., Portuguese women). Even groups with higher income but a lower incidence of breast feeding (e.g., German, French Canadian, and native white women) did not fare as well as income would suggest.

Two additional tables (7 and 8) provide results for the 1950s and 1960s. Table 6 presents data for single births to white mothers in New York state in 1950-1952. They are organized by the standard 1950 U.S. Census categories of husband's occupation. The results are both unadjusted and adjusted for birth weight and age of mother. They are also tabulated for different ages at death fetal, infant (0-365 days), neonatal (0-27 days), and post-neonatal (28-365 days). The gradients for the infant mortality rate by socioeconomic group are now smaller than previously, and they are also quite regular. The differences between the highest and the lowest groups are considerably smaller - about 60\% for infant mortality and 33\% for neonatal mortality. The differences are largest for the post-neonatal period when the influence of environmental circumstances is much more likely to affect the outcome.

Table 7 gives some data from the large matched birth and infant death study undertaken for the period 1964-1966 by the National Center for Health Statistics [see MacMahon, Kovar, and Feldman, 1972]. In this case, education of the father is used as the indicator of socioeconomic status., since birth and death certificates did not report occupation of the father. They still do not report that useful piece of information [NCHS, 1995, Section 4, pp. 1-3; NCHS, 1996a, Section 7, pp. 2-5]. By the 1960s, infant mortality rates had fallen considerably - from about 100 infant deaths per 1,000 live births for the Birth Registration Area in 1915, to about 72 for the Birth Registration Area in 1925, to about 56 in 1935, 34 in 1945, 26 in 1955 and 25 in 1965 (and 21 for the white population) [Carter, et al. 2006, Table Ab912-927]. But differentials by education and socioeconomic status were still considerable: a 78\% penalty for women with husband's with 8 or fewer years of education relative to women with husbands with a college education or more. The penalty was 49\% for neonatal mortality and $303 \%$ for post-neonatal mortality.

A similar study can be undertaken for the United states for a later period. The National Center for Health Statistics has been releasing the data from the "Linked Birth/Infant Death Studies" for birth cohorts from 1985 onwards. Table 8 reports 
tabulations made from those data for the birth cohort of 1991 [NCHS, 1996]. ${ }^{7}$ This data set contains information on 4,115,494 births and 35,520 infant deaths. Again the measure of socioeconomic status is the education level of the father. ${ }^{8}$ The results are reported by race (using the 1990 office of Management and Budget categories) and for infant, neonatal, and post-neonatal mortality rates. The gradients are still present, despite the drop in the overall infant mortality rate to 8.6 per 1,000 live births (7.0 for whites and 16.6 for blacks). Those with no formal education had infant mortality rates over twice as high as those who had some graduate education. The differences were also again larger for post neonatal mortality, though not dramatically so. It is unrealistic, however, to look at those results. Couples with a husband having no formal education contributed only .7\% of all births in the United States in 1991. The results are less dramatic for husband's with 1-7 years and with completed primary education ( 8 years of schooling). Quite large differences appear across racial and ethnic categories: Whites and Asian/Pacific Islanders do well. Blacks and American Indians, Eskimos, and Aleuts do poorly. The socioeconomic status gradients within groups remain and look similar. It is the concentration of blacks and Amerindians in low educational categories that relegates them to this harsh mortality penalty.

\section{CONCLUDING COMMENTS}

The studies and data sets surveyed in this paper are summarized in Table 9. Several additional studies (taken from Antonovsky and Bernstein [1977]) are also reported. The mortality ratios are the common measure, which give the ratio of the mortality rate for infants or children for the lowest socioeconomic status group to the mortality rate for the highest socioeconomic status group. The table shows some tendency for inequality to worsen from the 1890s to the 1920s. There was likely some improvement from the 1930s to the 1950s, in parallel with a general improvement in income distribution [Williamson and Lindert, 1980, pp. 82-94]. But differentials seem to have opened again, despite the overall decline in infant and child mortality. Social status gradients in infant mortality continue to exist and to be relatively large in relative terms (though now much smaller in absolute terms). There is currently a $50 \%$ to $150 \%$ penalty in infant mortality for being in the lowest

7 The CD-ROM versions are not especially easy to use for analytical purposes. The ASCII data are available from the National Center for Health Statistics. For an example of the application of these data, see Hummer, et al. [1999].

8 This was the last year for which education of the father was reported. 
socioeconomic status group relative to the highest one.

But race and ethnicity must be considered whenever looking at the American population and society. The serious disadvantage of the nonwhite population is traceable significantly to their low average levels of education and income. This is true especially for blacks but also for the Amerindian population. It also holds for the Hispanic population (both white and nonwhite), although that group is not analyzed here. The Asian/Pacific Islander population as a whole does not suffer from this mortality penalty. On two counts, the U.S. lags many other developed nations -- the level of health and medical care provided to the poor, and the standard of living of the poor. In 2005, the United States ranked $42^{\text {nd }}$ in the world in infant mortality. But even if all Americans has the same infant mortality rate as the white population (5.7), the United States would still only be tied for $38^{\text {th }}$ place [U.S. Bureau of the Census, 2008, Table 1295]. A wealthy and technologically advanced society surely can and should do more. As Antonovsky and Bernstein [1977, p. 459] note: "Low social class per se does not cause high infant mortality...however,...social class does subsume a large set of more directly causative biological and behavioral variables." Some of those causative variables may be amenable to direct policy intervention (e.g., universal child immunization programs), but some may be address by more general improvements in the living standards of the society, particularly among its poor. 


\section{REFERENCES}

Antonovsky, Aaron, and Judith Bernstein.1977. "Social Class and Infant Mortality." Social Science and Medicine. Vol.11, No.8/9 (May). pp. 453-477.

Bremner, Robert H., ed. 1971. Child and Youth in America: A Documentary History. Volume II: 1866-1932. Cambridge, MA: Harvard University Press.

Carter, Susan B., et al. 2006. Historical Statistics of the United States: Earliest Times to the Present. Millennial edition. NY: Cambridge University Press.

Chase, H.C. 1962. The Relationship of Certain Biologic and Socio-Economic Factors of Fetal, Infant, and Early Childhood Mortality. Albany, NY: New York state Department of Health.

Coale, Ansley J., and Paul Demeny. 1966. Regional Model Life Tables and Stable

Populations. Princeton, N.J.: Princeton University Press.

Council of Economic Advisers. 1996. Economic Report of the President. Washington, DC: G.P.O.

Dahrendorf, Ralf. 1979. Life Chances: Approaches to Social and Political Theory.

Chicago: University of Chicago Press.

Ewbank, Douglas C., and Samuel H. Preston. 1990. "Personal Health Behaviour and the Decline in Infant and Child Mortality." In What we Know About the Health Transition: The Cultural, Social, and Behavioral Determinants of Health. Edited by John Caldwell et al. Vol I. Canberra, Australia, Health Transition Centre. pp. 116-149.

Haines, Michael R. 1985. "Inequality and Childhood Mortality: A Comparison of England and Wales, 1911, and the United States, 1900." The Journal of Economic History.

Vol.45, No.4 (December). pp. 885-912.

Haines, Michael R. 1999. "The Urban Mortality Transition in the United States, $1800-$ 1940." Paper presented at the "The Demographic Forum 1999", Norwegian Academy of Sciences, Oslo, Norway, June 10-13.

Haines, Michael R., and Samuel H. Preston. 1997. "The Use of the Census to Estimate Childhood Mortality: Comparisons from the 1900 and 1910 United States Census Public Use Samples." Historical Methods. Vol. 30, No. 2 (Spring). pp. 77-97.

Hicks, Norman L., and Paul Streeten. 1975. "Indicators of Development: The Search for a Basic Needs Yardstick." World Development. Vol. 7 (June).

Hummer, Robert A., Monique Biegler, Peter B. De Turk, Dourglas Forbes, W. Parker Frisbee, Ying Hong, and Starling G. Pullum. 1999. "Race/Ethnicity, Nativity, and Infant Mortality in the United States." Social Forces. Vol. 77, No. 3. (March). pp. $1083-1118$.

Kuznets, Simon. 1966. Modern Economic Growth: Rate, Structure, and Spread. New Haven: Yale University Press.

Lindenmeyer, Kriste. 1997. "A Right to Childhood": The U.S. Children's Bureau and Child Welfare, 1912-46. Urbana, IL: University of Illinois Press.

MacMahon, B., M.G. Kovar, and J.J. Feldman. 1972. "Infant Mortality Rates: Socioeconomic Factors." Vital and Health Statistics. Series 22, No. 14. Rockville, MD: U.S. Department of Health, Education, and Welfare.

Meckel, Richard A. 1990. Save the Babies: American Public Health Reform and the Prevention of Infant Mortality, 1850-1929. Baltimore, MD: The Johns Hopkins University Press.

National Center for Health Statistics (NCHS). 1995. Vital Statistics of the United States, 1992. Vol. I. "Natality." Washington, DC: Public Health Service.

National Center for Health Statistics (NCHS). 1996a. Vital Statistics of the United States, 1992. Vol. II. "Mortality." Part A. Washington, DC: Public Health Service. 
National Center for Health Statistics (NCHS). 1996b. 1991 Birth Cohort Linked Birth Infant Death Data Set. CD-ROM Series 20, No. 7 (May). Hyattsville, MD: NCHS.

Overseas Development Council. 1979. The United States and World Development: Agenda, 1979. New York: Overseas Development Council.

Preston, Samuel H., and Michael R. Haines. 1991. Fatal Years: Child Mortality in the Late Nineteenth-Century America. (Princeton, NJ: Princeton University Press).

Preston, Samuel H., Douglas Ewbank, and Mark Hereward. 1994. "Child Mortality

Differences by Ethnicity and Race in the Unites States: 1900-1910." In After Ellis

Island: Newcomers and Natives in the 1910 Census, edited by Susan Cotts Watkins. NY: Russell Sage Foundation. pp. 35-82.

Titmuss, R.M. 1943. Birth, Poverty, and Wealth. London: Hamish Hamilton Medical Books.

United Nations. 1983. Indirect Techniques for Demographic Estimation. Manual X. New York: United Nations.

United Nations. United Nations Development Program. 1994. Human Development Report 1994. New York: Oxford University Press.

United Nations. United Nations Development Program. 1999. Human Development Report 1999. New York: Oxford University Press.

U.S. Bureau of the Census. 1926. Birth, stillbirth, and Infant Mortality Statistics for the Birth registration Area of the United States, 1924. Washington, DC: G.P.O.

U.S. Bureau of the Census. 1932. Birth, stillbirth, and Infant Mortality Statistics for the Birth registration Area of the United States, 1929. Washington, DC: G.P.O.

U.S. Bureau of the Census. 2008. Statistical Abstract of the United States, 2009. Washington, DC: G.P.O.

United States. Office of the President. Council of Economic Advisers. 1996. Economic Report of the President, 1996. Washington, DC: GPO.

Weber, Max. 1963 [1920]. "Class, Status, Party." In H.H. Gerth and C. Wright Mills. From Max Weber: Essays in Sociology. NY: Oxford University Press. pp. 180-196.

Williamson, Jeffrey G., and Peter Lindert. 1980. American Inequality: A Macroeconomic History. New York: Academic Press.

Woodbury, Robert Morse. 1926. Infant Mortality and its Causes. Baltimore: The Williams and Wilkins Company. 
Table 1. Child Mortality Index by Race, Residence, \& Occupation of Father. United States, 1900.

\begin{tabular}{|c|c|c|c|c|c|c|c|c|c|}
\hline & Total & $(\mathrm{CEB})$ & Urban & ( $\mathrm{CEB})$ & Rural & ( $\mathrm{CEB})$ & $\begin{array}{l}\text { Ratio to } \mathrm{Pr} \\
\text { Total }\end{array}$ & $\begin{array}{l}\text { fessio } \\
\text { Rural }\end{array}$ & $\begin{array}{l}\mathrm{nal} / \mathrm{Te} \\
\text { Urban }\end{array}$ \\
\hline All Women & 1.0007 & 39326 & 1.1231 & 16253 & 0.9149 & 23073 & 1.057 & 1.132 & 1.054 \\
\hline $\begin{array}{l}\text { Professional, Technical } \\
\text { Agricultural }\end{array}$ & 0.9465 & 943 & 0.9919 & 601 & 0.8678 & 342 & 1.000 & 1.000 & 1.000 \\
\hline $\begin{array}{l}\text { (excluding Laborers) } \\
\text { Managers, Officials, }\end{array}$ & 0.8651 & 15762 & 1.0917 & 678 & 0.8548 & 15084 & 0.914 & 1.101 & 0.985 \\
\hline Proprietors & 0.9358 & 2341 & 0.9421 & 1657 & 0.9207 & 684 & 0.989 & 0.950 & 1.061 \\
\hline Clerical & 0.9135 & 712 & 0.9169 & 598 & 0.8959 & 114 & 0.965 & 0.924 & 1.032 \\
\hline Sales & 0.8325 & 905 & 0.8478 & 771 & 0.7440 & 134 & 0.880 & 0.855 & 0.857 \\
\hline Craftsmen, Foremen & 1.1225 & 5676 & 1.1776 & 4266 & 0.9564 & 1410 & 1.186 & 1.187 & 1.102 \\
\hline Operatives & 1.0474 & 3916 & 1.0380 & 2656 & 1.0660 & 1260 & 1.107 & 1.047 & 1.229 \\
\hline Service Workers & 1.0025 & 868 & 0.9904 & 724 & 1.0639 & 144 & 1.059 & 0.998 & 1.226 \\
\hline Agricultural Laborers & 1.1467 & 1702 & 0.8515 & 154 & 1.1770 & 1548 & 1.212 & 0.858 & 1.356 \\
\hline Laborers & 1.2482 & 5947 & 1.3652 & 3732 & 1.0485 & 2215 & 1.319 & 1.376 & 1.208 \\
\hline Miscellaneous & 1.0065 & 554 & 1.0341 & 416 & 0.9253 & 138 & 1.063 & 1.043 & 1.066 \\
\hline White Women & 0.9359 & 34320 & 1.0725 & 15267 & 0.8271 & 19053 & 0.992 & 1.077 & 0.976 \\
\hline $\begin{array}{l}\text { Professional, Technical } \\
\text { Agricultural }\end{array}$ & 0.9432 & 907 & 0.9959 & 587 & 0.8474 & 320 & 1.000 & 1.000 & 1.000 \\
\hline $\begin{array}{l}\text { (excluding Laborers) } \\
\text { Managers, officials, }\end{array}$ & 0.7726 & 13190 & 1.0523 & 617 & 0.7588 & 12573 & 0.819 & 1.057 & 0.895 \\
\hline Clerical & 0.8835 & 695 & 0.9071 & 592 & 0.7441 & 103 & 0.937 & 0.911 & 0.878 \\
\hline Sales & 0.8366 & 893 & 0.8459 & 765 & 0.7809 & 128 & 0.887 & 0.849 & 0.922 \\
\hline Craftsmen, Foremen & 1.0985 & 5507 & 1.1479 & 4175 & 0.9442 & 1332 & 1.165 & 1.153 & 1.114 \\
\hline Operatives & 1.0044 & 3650 & 1.0091 & 2550 & 0.9938 & 1100 & 1.065 & 1.013 & 1.173 \\
\hline Service Workers & 0.9472 & 762 & 0.9600 & 642 & 0.8778 & 120 & 1.004 & 0.964 & 1.036 \\
\hline Agricultural Laborers & 0.9287 & 1035 & 0.7792 & 109 & 0.9465 & 926 & 0.985 & 0.782 & 1.117 \\
\hline Laborers & 1.1671 & 4880 & 1.2364 & 3210 & 1.0324 & 1670 & 1.237 & 1.241 & 1.218 \\
\hline Miscellaneous & 0.9556 & 508 & 0.9580 & 385 & 0.9483 & 123 & 1.013 & 0.962 & 1.119 \\
\hline Native White Women & 0.8682 & 25333 & 0.9727 & 9090 & 0.8103 & 16243 & 0.929 & 1.015 & 0.907 \\
\hline Professional, Technical & 0.9348 & 768 & 0.9588 & 486 & 0.8938 & 282 & 1.000 & 1.000 & 1.000 \\
\hline
\end{tabular}


Table 1 (cont.)

\begin{tabular}{|c|c|c|c|c|c|c|}
\hline & Total & ( $\mathrm{CEB})$ & Urban & $(\mathrm{CEB})$ & Rural & ( $\mathrm{CEB}$ ) \\
\hline \multicolumn{7}{|l|}{ Agricultural } \\
\hline \multicolumn{7}{|l|}{ Managers, Officials, } \\
\hline Proprietors & 0.8857 & 1744 & 0.8645 & 1172 & 0.9290 & 572 \\
\hline Clerical & 0.8466 & 577 & 0.8642 & 483 & 0.7541 & 94 \\
\hline Sales & 0.7659 & 634 & 0.7559 & 517 & 0.8095 & 117 \\
\hline Craftsmen, Foremen & 1.0119 & 3627 & 1.0523 & 2467 & 0.9268 & 1160 \\
\hline Operatives & 0.9830 & 2243 & 0.9990 & 1470 & 0.9516 & 773 \\
\hline Service Workers & 0.9261 & 501 & 0.9767 & 400 & 0.7248 & 101 \\
\hline Agricultural Laborers & 0.8917 & 862 & 0.7280 & 88 & 0.9106 & 774 \\
\hline Laborers & 1.0466 & 2833 & 1.0481 & 1412 & 1.0452 & 1421 \\
\hline Miscellaneous & 0.8045 & 306 & 0.8530 & 199 & 0.7173 & 107 \\
\hline Foreign White Women & 1.1247 & 8941 & 1.2163 & 6163 & 0.9237 & 2778 \\
\hline Professional, Technical \1 & 0.9929 & 138 & 1.1777 & 100 & 0.5294 & 58 \\
\hline \multicolumn{7}{|l|}{ Agricultural } \\
\hline (excluding Laborers) & 0.8867 & 1922 & 1.1960 & 221 & 0.8466 & 1701 \\
\hline \multicolumn{7}{|l|}{ Managers, Officials, } \\
\hline Proprietors & 1.1202 & 549 & 1.1492 & 463 & 0.9625 & 86 \\
\hline Clerical\1 & 1.0586 & 118 & 1.0902 & 109 & 0.6350 & 58 \\
\hline Sales $\backslash 1$ & 1.0041 & 259 & 1.0267 & 248 & 0.5294 & 58 \\
\hline Craftsmen, Foremen & 1.2606 & 1873 & 1.2813 & 1701 & 0.5294 & 172 \\
\hline Operatives & 1.0314 & 1401 & 1.0160 & 1076 & 1.0823 & 325 \\
\hline Service Workers & 0.9880 & 261 & 0.9322 & 242 & * & * \\
\hline Agricultural Laborers & 1.1046 & 173 & * & * & 1.1208 & 152 \\
\hline Laborers & 1.3312 & 2047 & 1.3822 & 1798 & 0.9609 & 249 \\
\hline Miscellaneous & 1.1948 & 200 & 1.0807 & 184 & * & * \\
\hline Black Women & 1.4440 & 4870 & 1.9582 & 963 & 1.3210 & 3907 \\
\hline Professional, Technical \2 & 0.8388 & 100 & 0.9550 & 46 & 0.7478 & 54 \\
\hline \multirow{4}{*}{$\begin{array}{l}\text { Agricultural } \\
\text { (excluding Laborers) } \\
\text { Managers, Officials, } \\
\text { Proprietors } \backslash 2\end{array}$} & & & & & & \\
\hline & 1.3281 & 2529 & 1.5156 & 61 & 1.3237 & 2468 \\
\hline & & & & & & \\
\hline & 0.8388 & 100 & 0.9550 & 46 & 0.7478 & 54 \\
\hline
\end{tabular}

Ratio to Professional/Technical Total Rural Urban

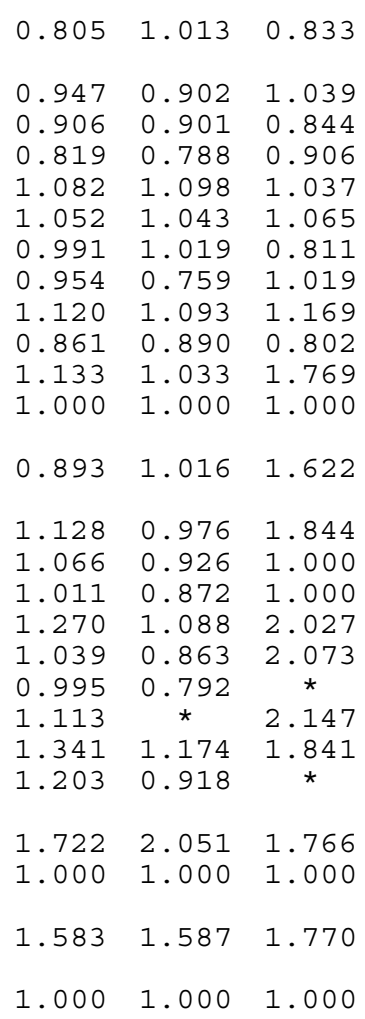


Table 1 (cont.)

Total (CEB) Urban (CEB) Rural (CEB) $\begin{gathered}\text { Ratio to Professional/Technical } \\ \text { Total Rural Urban }\end{gathered}$

\begin{tabular}{|c|c|c|c|c|c|c|c|c|c|}
\hline Clerical $\backslash 2$ & 0.8388 & 100 & 0.9550 & 46 & 0.7478 & 54 & 1.000 & 1.000 & 1.000 \\
\hline Sales $\backslash 2$ & 0.8388 & 100 & 0.9550 & 46 & 0.7478 & 54 & 1.000 & 1.000 & 1.000 \\
\hline Craftsmen, Foremen & 1.9214 & 166 & 2.6456 & 91 & 1.0766 & 75 & 2.291 & 2.770 & 1.440 \\
\hline Operatives & 1.6330 & 266 & 1.7393 & 106 & 1.5633 & 160 & 1.947 & 1.821 & 2.090 \\
\hline Service Workers & 1.3668 & 88 & 1.2491 & 82 & * & * & 1.629 & 1.308 & * \\
\hline Agricultural Laborers & 1.4926 & 643 & 1.0198 & 45 & 1.5306 & 598 & 1.779 & 1.068 & 2.047 \\
\hline Laborers & 1.6456 & 1032 & 2.2338 & 501 & 1.0938 & 531 & 1.962 & 2.339 & 1.463 \\
\hline Miscellaneous & 1.5575 & 46 & * & * & * & * & 1.857 & * & * \\
\hline
\end{tabular}

Source: IPUMS sample of census enumerators' manuscripts, U.S. 1900.

Note: Sample consists of currently married women, married 0-24 years. The mortality index is the ratio of actual to expected child deaths. See text for the calculation of the expected child deaths. Unknown categories not reported. Only women with husband present are eligible for the calculation.

$\backslash 1$ Combined Professional and Technical; Clerical; and Sales.

12 Combined Professional and Technical; Managers, etc.; Clerical; and Sales.

* Fewer than 40 children ever born in the category. 
Table 2. Child Mortality Index by Race, Residence, \& Occupation of Father. United States, 1910.

\begin{tabular}{|c|c|c|c|c|c|c|c|c|c|}
\hline & Total & ( $\mathrm{CEB})$ & Urban & $(\mathrm{CEB})$ & Rural & ( $\mathrm{CEB})$ & $\begin{array}{c}\text { Ratio to Prof } \\
\text { Total }\end{array}$ & $\begin{array}{l}\text { ession } \\
\text { Rural }\end{array}$ & $\begin{array}{l}\text { al/Tec } \\
\text { Urban }\end{array}$ \\
\hline All Women & 1.0000 & 115198 & 1.0706 & 53562 & 0.9389 & 61636 & 1.168 & 1.265 & 1.063 \\
\hline $\begin{array}{l}\text { Professional, Technical } \\
\text { Agricultural }\end{array}$ & 0.8564 & 2700 & 0.8467 & 1980 & 0.8832 & 720 & 1.000 & 1.000 & 1.000 \\
\hline $\begin{array}{l}\text { (excluding Laborers) } \\
\text { Managers, Officials, }\end{array}$ & 0.8962 & 40290 & 0.8962 & 1234 & 0.8962 & 39056 & 1.046 & 1.059 & 1.015 \\
\hline Proprietors & 0.9260 & 11231 & 0.9555 & 8519 & 0.8331 & 2712 & 1.081 & 1.128 & 0.943 \\
\hline Clerical & 0.8613 & 3106 & 0.9013 & 2548 & 0.6780 & 558 & 1.006 & 1.064 & 0.768 \\
\hline Sales & 0.8171 & 3371 & 0.8471 & 2845 & 0.6517 & 526 & 0.954 & 1.000 & 0.738 \\
\hline Craftsmen, Foremen & 0.9836 & 17441 & 1.0055 & 13547 & 0.9074 & 3894 & 1.149 & 1.188 & 1.027 \\
\hline Operatives & 1.1499 & 15411 & 1.1307 & 11065 & 1.1988 & 4346 & 1.343 & 1.335 & 1.357 \\
\hline Service Workers & 1.1878 & 3268 & 1.1979 & 2851 & 1.1177 & 417 & 1.387 & 1.415 & 1.266 \\
\hline Agricultural Laborers & 1.1261 & 6788 & 1.2698 & 806 & 1.1060 & 5982 & 1.315 & 1.500 & 1.252 \\
\hline Laborers & 1.2673 & 11592 & 1.3687 & 8167 & 1.0205 & 3425 & 1.480 & 1.617 & 1.155 \\
\hline White Women & 0.9467 & 102730 & 1.0325 & 50713 & 0.8634 & 52017 & 1.164 & 1.298 & 1.001 \\
\hline $\begin{array}{l}\text { Professional, Technical } \\
\text { Agricultural }\end{array}$ & 0.8130 & 2544 & 0.7952 & 1875 & 0.8628 & 669 & 1.000 & 1.000 & 1.000 \\
\hline $\begin{array}{l}\text { (excluding Laborers) } \\
\text { Managers, Officials, }\end{array}$ & 0.8200 & 33580 & 0.7788 & 1075 & 0.8214 & 32505 & 1.009 & 0.979 & 0.952 \\
\hline Proprietors & 0.9189 & 11096 & 0.9497 & 8425 & 0.8211 & 2671 & 1.130 & 1.194 & 0.952 \\
\hline Clerical & 0.8402 & 3050 & 0.8810 & 2499 & 0.6540 & 551 & 1.033 & 1.108 & 0.758 \\
\hline Sales & 0.8135 & 3363 & 0.8437 & 2842 & 0.6458 & 521 & 1.001 & 1.061 & 0.748 \\
\hline Craftsmen, Foremen & 0.9695 & 17036 & 0.9933 & 13258 & 0.8856 & 3778 & 1.192 & 1.249 & 1.026 \\
\hline Operatives & 1.1168 & 14572 & 1.1070 & 10617 & 1.1420 & 3955 & 1.374 & 1.392 & 1.324 \\
\hline Service Workers & 1.1179 & 2798 & 1.1167 & 2419 & 1.1256 & 379 & 1.375 & 1.404 & 1.305 \\
\hline Agricultural Laborers & 0.9842 & 4909 & 1.2361 & 664 & 0.9433 & 4245 & 1.211 & 1.555 & 1.093 \\
\hline Laborers & 1.1770 & 9782 & 1.2798 & 7039 & 0.9080 & 2743 & 1.448 & 1.609 & 1.052 \\
\hline Native White Wo & 0.8813 & 75614 & 0.9203 & 30138 & 0.8557 & 45476 & 1.141 & 1.265 & 0.972 \\
\hline Professional, Technical & 0.7723 & 2216 & 0.7276 & 1567 & 0.8800 & 649 & 1.000 & 1.000 & 1.000 \\
\hline
\end{tabular}


Table 2 (cont.)

\begin{tabular}{|c|c|c|c|c|c|c|}
\hline & Total & ( $\mathrm{CEB})$ & Urban & ( CEB ) & Rural & ( $\mathrm{CEB}$ ) \\
\hline \multicolumn{7}{|l|}{ Agricultural } \\
\hline \multicolumn{7}{|l|}{ Managers, Officials, } \\
\hline Proprietors & 0.8391 & 7559 & 0.8524 & 5186 & 0.8100 & 2373 \\
\hline Clerical & 0.7871 & 2571 & 0.8262 & 2062 & 0.6278 & 509 \\
\hline Sales & 0.8006 & 2680 & 0.8260 & 2218 & 0.6763 & 462 \\
\hline Craftsmen, Foremen & 0.8997 & 11115 & 0.9052 & 7910 & 0.8863 & 3205 \\
\hline Operatives & 1.0259 & 8533 & 1.0112 & 5756 & 1.0560 & 2777 \\
\hline Service Workers & 0.9939 & 1730 & 0.9635 & 1397 & 1.1218 & 333 \\
\hline Agricultural Laborers & 0.9626 & 4040 & 1.2616 & 350 & 0.9333 & 3690 \\
\hline Laborers & 1.0558 & 5107 & 1.1474 & 2848 & 0.9383 & 2259 \\
\hline Foreign White Women & 1.1271 & 27099 & 1.1952 & 20561 & 0.9160 & 6538 \\
\hline Professional, Technical & 1.0827 & 328 & 1.1322 & 308 & 1.0827 & \\
\hline Agricultural & & & & & & \\
\hline (excluding Laborers) & 0.8002 & 3515 & 0.9424 & 231 & 0.7901 & 3284 \\
\hline \multicolumn{7}{|l|}{ Managers, officials, } \\
\hline Proprietors & 1.0874 & 3536 & 1.1041 & 3239 & 0.9090 & 297 \\
\hline Clerical & 1.1170 & 479 & 1.1339 & 437 & 0.9491 & 42 \\
\hline Sales & 0.8638 & 683 & 0.9066 & 624 & 0.4096 & 59 \\
\hline Craftsmen, Foremen & 1.0988 & 5912 & 1.1224 & 5339 & 0.8820 & 573 \\
\hline Operatives & 1.2433 & 6035 & 1.2186 & 4857 & 1.3463 & 1178 \\
\hline Service Workers & 1.3169 & 1068 & 1.3244 & 1022 & 1.1524 & 46 \\
\hline Agricultural Laborers & 1.0818 & 868 & 1.2111 & 313 & 1.0074 & 555 \\
\hline Laborers & 1.3073 & 4675 & 1.3690 & 4191 & 0.7695 & 484 \\
\hline Black Women & 1.4427 & 11800 & 1.7714 & 2600 & 1.3514 & 9200 \\
\hline Professional, Technical \1 & 1.4859 & 281 & 1.6446 & 230 & 0.7670 & 51 \\
\hline \\
\hline (excluding Laborers) & 1.2729 & 6525 & 1.2957 & 114 & 1.2725 & 6411 \\
\hline \multicolumn{7}{|l|}{ Managers, Officials, } \\
\hline Proprietors \1 & 1.4859 & 281 & 1.6446 & 230 & 0.7670 & 51 \\
\hline Clerical\1 & 1.4859 & 281 & 1.6446 & 230 & 0.7670 & 51 \\
\hline
\end{tabular}

Ratio to Professional/Technical Total Rural Urban
$\begin{array}{lll}1.065 & 1.008 & 0.938\end{array}$
$\begin{array}{lll}1.086 & 1.171 & 0.920\end{array}$
$\begin{array}{lll}1.019 & 1.136 & 0.713\end{array}$
$\begin{array}{lll}1.037 & 1.135 & 0.769\end{array}$
$\begin{array}{lll}1.165 & 1.244 & 1.007\end{array}$
$1.328 \quad 1.390 \quad 1.200$
$\begin{array}{lll}1.287 & 1.324 & 1.275\end{array}$
$1.246 \quad 1.734 \quad 1.061$
$\begin{array}{lll}1.367 & 1.577 & 1.066\end{array}$
$\begin{array}{lll}1.041 & 1.056 & 0.846\end{array}$
$1.000 \quad 1.000 \quad 1.000$
$\begin{array}{lll}0.739 & 0.832 & 0.730\end{array}$
$\begin{array}{llll}1.004 & 0.975 & 0.840\end{array}$
$\begin{array}{lll}1.032 & 1.002 & 0.877\end{array}$
$\begin{array}{llll}0.798 & 0.801 & 0.378\end{array}$
$\begin{array}{lll}1.015 & 0.991 & 0.815\end{array}$
$1.148 \quad 1.076 \quad 1.243$
$\begin{array}{lll}1.216 & 1.170 & 1.064\end{array}$
$0.999 \quad 1.070 \quad 0.930$
$1.208 \quad 1.209 \quad 0.711$

$\begin{array}{lll}0.971 & 1.077 & 1.762 \\ 1.000 & 1.000 & 1.000 \\ 0.857 & 0.788 & 1.659 \\ & & \\ 1.000 & 1.000 & 1.000 \\ 1.000 & 1.000 & 1.000\end{array}$


Table 2 (cont.)

\begin{tabular}{|c|c|c|c|c|c|c|c|c|c|}
\hline & Total & $(\mathrm{CEB})$ & Urban & ( $\mathrm{CEB})$ & Rural & $(\mathrm{CEB})$ & $\begin{array}{r}\text { Ratio to } \mathrm{P} \\
\text { Total }\end{array}$ & $\begin{array}{l}\text { Ofessi } \\
\text { Rural }\end{array}$ & $\begin{array}{l}\text { Dnal/T } \\
\text { Urbar }\end{array}$ \\
\hline Sales \1 & 1.4859 & 281 & 1.6446 & 230 & 0.7670 & 51 & 1.000 & 1.000 & 1.000 \\
\hline Craftsmen, Foremen & 1.4992 & 359 & 1.4446 & 251 & 1.6287 & 108 & 1.009 & 0.878 & 2.123 \\
\hline Operatives & 1.7903 & 798 & 1.7487 & 432 & 1.8393 & 366 & 1.205 & 1.063 & 2.398 \\
\hline Service Workers & 1.6705 & 447 & 1.7257 & 409 & 1.0322 & 38 & 1.124 & 1.049 & 1.346 \\
\hline Agricultural Laborers & 1.5199 & 1717 & 1.4403 & 132 & 1.5268 & 1585 & 1.023 & 0.876 & 1.990 \\
\hline Laborers & 1.7896 & 1673 & 1.9810 & 1032 & 1.4771 & 641 & 1.204 & 1.205 & 1.926 \\
\hline
\end{tabular}

Source: IPUMS sample of census enumerators' manuscripts, U.S. 1910 .

Note: Sample consists of currently married women, married 0-24 years. The mortality index is the ratio of actual to expected child deaths. See text for the calculation of the expected child deaths. Unknown categories not reported. only women with husband present are eligible for the calculation.

$\backslash 1$ Value for rural taken as the average for all foreign-born white women with spouses in Professional and Technical occupations.

12 Combined Professional and Technical; Managers, etc.; Clerical; and Sales.

* Fewer than 40 children ever born in the category. 
Table 3. Estimated $\mathrm{q}(2)$ and $\mathrm{q}(5)$ by Occupation of Father. U.S. Birth Registration Area. 1924.(a)

\begin{tabular}{|c|c|c|c|c|c|c|}
\hline \multirow[b]{2}{*}{ OCCUPATION } & \multicolumn{5}{|c|}{ Ratio to } & \multirow[t]{2}{*}{ Ratio } \\
\hline & \multicolumn{2}{|c|}{ Prof/Tech } & Prof/Tech & $q(5)$ & $\mathrm{CEB}$ & \\
\hline All Occupations & 0.05800 & 958423 & 2.043 & 0.12909 & 1406406 & 1.462 \\
\hline Professional, Technical & 0.02839 & 18060 & 1.000 & 0.08827 & 36042 & 1.000 \\
\hline Farmers & 0.06067 & 210679 & 2.137 & 0.11324 & 375007 & 1.283 \\
\hline $\begin{array}{l}\text { Managers, Officials, } \\
\text { Proprietors }\end{array}$ & 0.04165 & 49396 & 1.467 & 0.10678 & 101513 & 1.210 \\
\hline Clerical & 0.03471 & 42624 & 1.223 & 0.09472 & 46904 & 1.073 \\
\hline Sales & 0.03296 & 5633 & 1.161 & 0.10376 & 11541 & 1.175 \\
\hline Craftsmen, Foremen & 0.04984 & 170193 & 1.756 & 0.12473 & 244569 & 1.413 \\
\hline Operatives & 0.05760 & 183208 & 2.029 & 0.13939 & 227309 & 1.579 \\
\hline Service Workers & 0.06136 & 24967 & 2.162 & 0.14167 & 33655 & 1.605 \\
\hline Agricultural Laborers & 0.07799 & 54190 & 2.747 & 0.15316 & 59908 & 1.735 \\
\hline Laborers & 0.07320 & 199473 & 2.579 & 0.16276 & 269958 & 1.844 \\
\hline
\end{tabular}

(a) Estimated by indirect methods described in United Nations, Manual $\mathrm{x}$, Indirect Techniques for Demographic Estimation (NY: United Nations, 1983), ch. III. q(2) is the probability of dying before reaching age $2 . q(5)$ is the probability of dying before reaching age 5 .

Source: U.S. Bureau of the Census, Birth, Stillbirth, and Infant Mortality Statistics for the Birth Registration Area of the United States, 1924 (Wash, DC: GPO, 1926), Table 10 . 
Table 4. Estimated $\mathrm{q}(2)$ and $\mathrm{q}(5)$ by Occupation of Father. U.S. Birth Registration Area. 1929. (a)

\begin{tabular}{|c|c|c|c|c|c|c|}
\hline & & & Ratio to & & & Ratio \\
\hline YEAR/OCCUPATION & $q(2)$ & $\mathrm{CEB}$ & Prof/Tech & $\begin{array}{l}\text { to } \\
q(5)\end{array}$ & $\mathrm{CEB}$ & $\begin{array}{l}\text { Prof /T } \\
\text { ech }\end{array}$ \\
\hline All Occupations & 0.04812 & 1155931 & 2.249 & 0.10325 & 1434700 & 1.605 \\
\hline Professional, Technical & 0.02140 & 23476 & 1.000 & 0.06434 & 39479 & 1.000 \\
\hline $\begin{array}{l}\text { Farmers } \\
\text { Managers officials }\end{array}$ & 0.05336 & 280794 & 2.494 & 0.09461 & 426099 & 1.470 \\
\hline $\begin{array}{l}\text { Managers, Officials, } \\
\text { Proprietors }\end{array}$ & 0.03074 & 52286 & 1.437 & 0.07987 & 100529 & 1.241 \\
\hline Clerical & 0.02580 & 46700 & 1.206 & 0.07493 & 50220 & 1.165 \\
\hline Sales & 0.02420 & 6132 & 1.131 & 0.06653 & 12757 & 1.034 \\
\hline Craftsmen, Foremen & 0.03904 & 184939 & 1.824 & 0.09814 & 227050 & 1.525 \\
\hline Operatives & 0.04723 & 215705 & 2.207 & 0.10796 & 226252 & 1.678 \\
\hline Service Workers & 0.04676 & 33351 & 2.185 & 0.10916 & 39412 & 1.697 \\
\hline Agricultural Laborers & 0.06382 & 62814 & 2.982 & 0.12680 & 58225 & 1.971 \\
\hline Laborers & 0.06130 & 249734 & 2.865 & 0.13737 & 254677 & 2.135 \\
\hline
\end{tabular}

(a) Estimated by indirect methods described in United Nations, Manual $\mathrm{x}$, Indirect Techniques for Demographic Estimation (NY: United Nations, 1983), ch. III. q(2) is the probability of dying before reaching age $2 . q(5)$ is the probability of dying before reaching age 5 .

Source: U.S. Bureau of the Census, Birth, Stillbirth, and Infant Mortality Statistics for the Birth Registration Area of the United States, 1929 (Wash, DC: GPO, 1932), Table 10 . 
TABLE 5. INFANT MORTALITY. EIGHT AMERICAN CITIES, 1911-1915. (a)

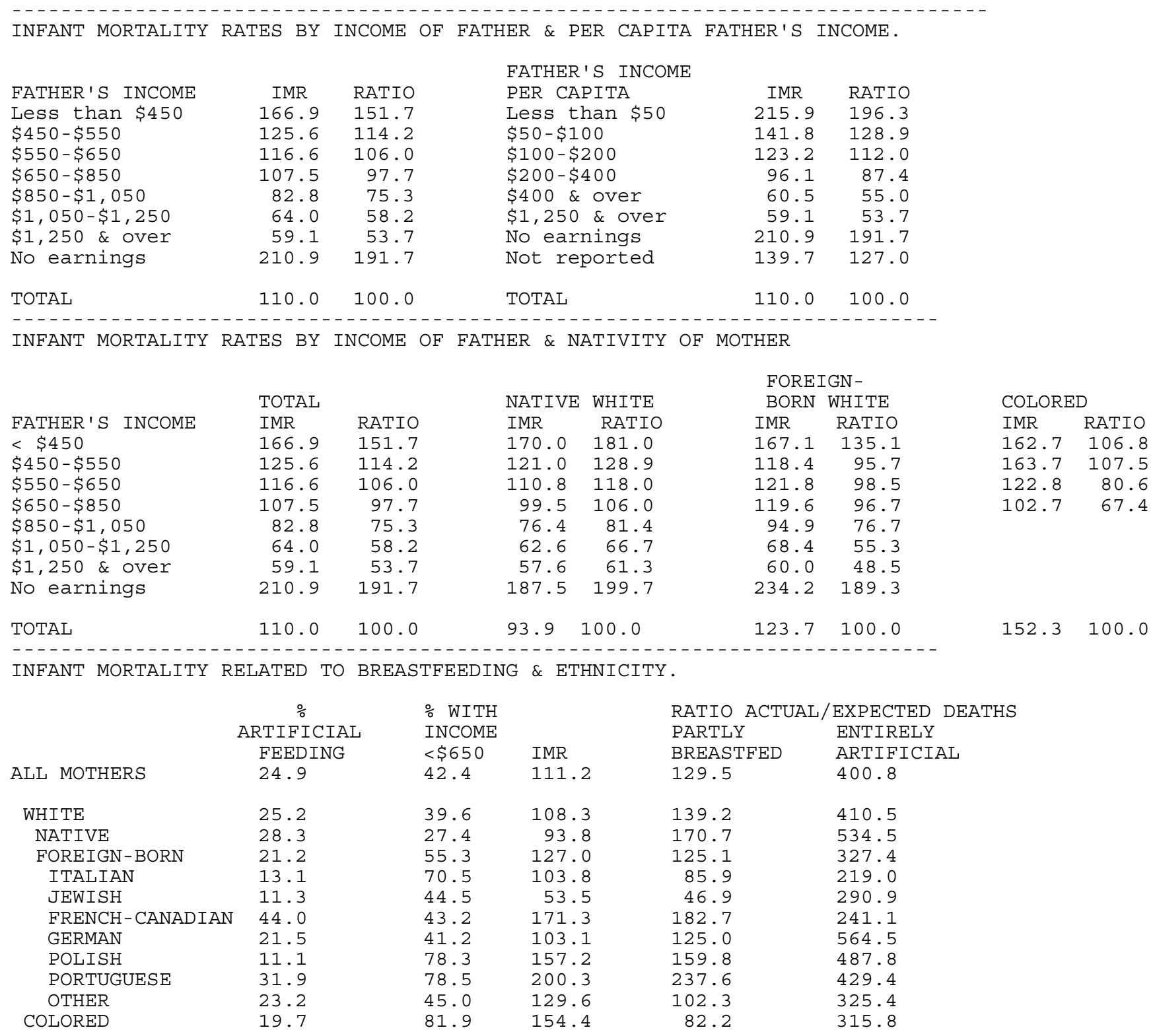


Table 5 (cont.)

\begin{tabular}{|c|c|c|c|c|}
\hline \multirow[t]{2}{*}{ TYPES OF FEEDING BY } & $\begin{array}{l}\text { COLOR AND ETHNICITY } \\
\text { TOTAL MONTHS }\end{array}$ & \multicolumn{3}{|l|}{ OF MOTHER. } \\
\hline & $\begin{array}{l}\text { TOTAL MONTHS } \\
\text { LIVED FROM } \\
\text { BIRTH TO END } \\
\text { OF } 9 \text { th MONTH }\end{array}$ & $\begin{array}{l}\% \text { OF MOS. } \\
\text { EXCLUSIVELY } \\
\text { BREASTFED }\end{array}$ & $\begin{array}{l}\% \text { OF MOS. } \\
\text { PARTLY } \\
\text { BREASTFED }\end{array}$ & $\begin{array}{l}\% \text { OF MOS. } \\
\text { ARTIFICIALLY } \\
\text { FED }\end{array}$ \\
\hline ALL MOTHERS & 192212.5 & 57.4 & 17.6 & 24.9 \\
\hline WHITE & 180397.5 & 57.6 & 17.1 & 25.2 \\
\hline NATIVE & 102285.5 & 56.2 & 15.4 & 28.3 \\
\hline FOREIGN-BORN & 78112.0 & 59.4 & 19.3 & 21.1 \\
\hline ITALIAN & 11943.0 & 68.6 & 18.3 & 13.1 \\
\hline JEWISH & 10688.0 & 61.5 & 27.1 & 11.3 \\
\hline FRENCH - CANADIAN & 8666.0 & 42.7 & 13.3 & 44.0 \\
\hline GERMAN & 6514.0 & 56.5 & 22.0 & 21.5 \\
\hline POLISH & 10391.5 & 65.9 & 22.7 & 11.1 \\
\hline PORTUGUESE & 5410.5 & 48.8 & 19.3 & 31.9 \\
\hline OTHER & 24471.0 & 60.3 & 16.5 & 23.2 \\
\hline NOT GIVEN & 18.0 & 27.8 & 33.3 & 38.9 \\
\hline COLORED & 11815.0 & 54.8 & 25.5 & 19.7 \\
\hline
\end{tabular}

(a) Cities were: Johnstown, PA; Manchester, NH; Saginaw, MI; Brockton, MA; New Bedford, MA; Waterbury, CT; Akron, $\mathrm{OH}$; and Baltimore, MD. The study was based on samples totaling 22,967 live births and 2,555 infant deaths.

SOURCE: Woodbury (1925, 1926). 
Table 6. Fetal, Infant, Neonatal, and Postneonatal Mortality Rates and Ratios.

By Father's Occupation. Single White Births. New York State, 1950-52.

\begin{tabular}{|c|c|c|c|c|c|c|c|c|}
\hline \multirow{3}{*}{$\begin{array}{l}\text { Father's } \\
\text { Occupation }\end{array}$} & \multicolumn{4}{|c|}{ Mortality Rates } & \multicolumn{4}{|c|}{ Mortality Ratios } \\
\hline & & nfant & $\mathrm{NeO}-$ & Post - & & ifant & Neo- & Post- \\
\hline & Fetal (b) & & natal & neonatal & Fetal (b) & & natal & neonata. \\
\hline \multicolumn{9}{|l|}{ UNADJUSTED } \\
\hline Professional & 12.8 & 17.8 & 14.1 & 3.7 & 100 & 100 & 100 & 100 \\
\hline Managerial & 13.3 & 18.7 & 15.2 & 3.5 & 104 & 105 & 108 & 95 \\
\hline Sales & 14.3 & 19.6 & 15.0 & 4.6 & 112 & 110 & 106 & 124 \\
\hline Clerical & 14.8 & 18.2 & 14.3 & 3.9 & 116 & 102 & 101 & 105 \\
\hline Craftsmen & 15.5 & 21.0 & 16.0 & 5.0 & 121 & 118 & 113 & 135 \\
\hline Operatives & 17.7 & 23.4 & 17.4 & 6.0 & 138 & 131 & 123 & 162 \\
\hline Services & 17.7 & 23.8 & 18.2 & 5.6 & 138 & 134 & 129 & 151 \\
\hline Non-Farm Labor & 17.8 & 28.4 & 18.8 & 9.6 & 139 & 160 & 133 & 259 \\
\hline All Occupations & 15.8 & 21.6 & 16.3 & 5.3 & 123 & 121 & 116 & 143 \\
\hline \multicolumn{9}{|l|}{ ADJUSTED (a) } \\
\hline Professional & 13.6 & 19.1 & 15.3 & 3.8 & 100 & 100 & 100 & 100 \\
\hline Managerial & 12.8 & 19.6 & 16.0 & 3.6 & 94 & 103 & 105 & 95 \\
\hline Sales & 14.2 & 19.7 & 15.0 & 4.7 & 104 & 103 & 98 & 124 \\
\hline Clerical & 15.7 & 19.1 & 15.2 & 3.9 & 115 & 100 & 99 & 103 \\
\hline Craftsmen & 15.7 & 21.0 & 16.0 & 5.0 & 115 & 110 & 105 & 132 \\
\hline Operatives & 17.5 & 22.6 & 16.7 & 5.9 & 129 & 118 & 109 & 155 \\
\hline Services & 16.6 & 22.8 & 17.1 & 5.7 & 122 & 119 & 112 & 150 \\
\hline Non-Farm Labor & 17.8 & 27.3 & 18.1 & 9.1 & 131 & 143 & 118 & 239 \\
\hline All Occupations & 15.8 & 21.6 & 16.3 & 5.3 & 116 & 113 & 107 & 139 \\
\hline
\end{tabular}

(a) Adjusted for birth weight and mother's age.

(b) Fetal deaths from the 20th week of gestation per 1,000 live births plus fetal deaths.

Source: Chase [1962] adapted by Antonovsky and Bernstein [1977], Table 15A. 
Table 7. Estimated Infant Mortality Rates and Ratios. By Education of Father and Age at Death. Legitimate White Live Births. United States. 1964-66.

\begin{tabular}{|c|c|c|c|c|c|c|c|c|}
\hline $\begin{array}{l}\text { Education of } \\
\text { Father }\end{array}$ & $\begin{array}{l}\text { Infant } \\
\text { Mort. }\end{array}$ & $\begin{array}{l}\text { Neo- } \\
\text { natal }\end{array}$ & $\begin{array}{l}\text { Less } \\
\text { than } \\
1 \text { day }\end{array}$ & $\begin{array}{l}1-6 \\
\text { days }\end{array}$ & $\begin{array}{l}7-27 \\
\text { days }\end{array}$ & $\begin{array}{l}\text { Post- } \\
\text { neo- } \\
\text { natal }\end{array}$ & $\begin{array}{l}1-5 \\
\text { mos. }\end{array}$ & $\begin{array}{l}6-11 \\
\text { mos. }\end{array}$ \\
\hline \multicolumn{9}{|l|}{ MORTALITY RATES } \\
\hline 16 years or more & 17.0 & 13.8 & 8.1 & 4.8 & 0.9 & 3.2 & 2.4 & 0.8 \\
\hline $13-15$ years & 19.0 & 15.9 & 9.9 & 4.9 & 1.1 & 3.1 & 2.0 & 1.1 \\
\hline 12 years & 17.6 & 13.7 & 8.0 & 4.7 & 1.0 & 3.9 & 3.0 & 0.9 \\
\hline 9-11 years & 23.9 & 17.6 & 10.2 & 5.7 & 1.7 & 6.3 & 4.0 & 2.3 \\
\hline 8 years or less & 30.3 & 20.6 & 11.0 & 6.8 & 2.8 & 9.7 & 6.9 & 2.8 \\
\hline All levels & 20.8 & 15.8 & 9.1 & 5.3 & 1.4 & 5.0 & 3.5 & 1.5 \\
\hline \multicolumn{9}{|l|}{ MORTALITY RATIOS } \\
\hline 16 years or more & 100 & 100 & 100 & 100 & 100 & 100 & 100 & 100 \\
\hline 13-15 years & 112 & 115 & 122 & 102 & 122 & 97 & 83 & 138 \\
\hline 12 years & 104 & 99 & 99 & 98 & 111 & 122 & 125 & 113 \\
\hline 9-11 years & 141 & 128 & 126 & 119 & 189 & 197 & 167 & 288 \\
\hline 8 years or less & 178 & 149 & 136 & 142 & 311 & 303 & 288 & 350 \\
\hline All levels & 122 & 114 & 112 & 110 & 156 & 156 & 146 & 188 \\
\hline
\end{tabular}

Source: MacMahon, Kovar, and Feldman [1972], adapted from Antonovsky and Bernstein [1977], Table 26A. 
Table 8. Infant Mortality Rates (per 100,000 Live Births) by Race of Mother \& Education of Father. United States. 1991.

\begin{tabular}{|c|c|c|c|c|c|c|}
\hline $\begin{array}{l}\text { Education } \\
\text { of Father }\end{array}$ & $\begin{array}{l}\text { All } \\
\text { Races }\end{array}$ & ace of & $\begin{array}{c}\text { lother } \\
\text { All } \\
\text { Other }\end{array}$ & Black & $\begin{array}{l}\text { American } \\
\text { Indian }\end{array}$ & $\begin{array}{l}\text { Asian \& } \\
\text { Pacific } \\
\text { Islander }\end{array}$ \\
\hline INFANT MORTALITY RATE & & & & & & \\
\hline $\begin{array}{l}\text { Total } \\
\text { No Formal Education }\end{array}$ & $\begin{array}{r}863.1 \\
1081.5\end{array}$ & $\begin{array}{r}705.4 \\
1033.0\end{array}$ & $\begin{array}{l}1451.4 \\
1235.6\end{array}$ & $\begin{array}{l}1658.3 \\
2154.9\end{array}$ & $\begin{array}{c}1132.7 \\
*\end{array}$ & $\begin{array}{c}580.7 \\
*\end{array}$ \\
\hline 1-7 Years & 690.3 & 678.7 & 832.7 & 1049.3 & * & 720.3 \\
\hline Completed Primary & 945.1 & 914.7 & 1254.8 & 1488.0 & * & * \\
\hline 9-11 Years & 927.3 & 845.3 & 1366.1 & 1499.3 & 1017.5 & 744.9 \\
\hline Completed High School & 785.1 & 686.0 & 1226.0 & 1365.2 & 886.5 & 599.5 \\
\hline 1-3 Years College & 634.5 & 563.6 & 1005.8 & 1202.3 & 869.2 & 454.9 \\
\hline Completed College & 497.8 & 460.0 & 785.6 & 1070.3 & * & 474.8 \\
\hline Graduate Education & 483.5 & 467.7 & 595.0 & 815.4 & * & 483.0 \\
\hline Not stated & 1522.2 & 1164.4 & 1967.2 & 2044.1 & 1472.0 & 929.6 \\
\hline MORTALITY RATIOS & & & & & & \\
\hline Total & 179 & 151 & 244 & 203 & 130 & 120 \\
\hline No Formal Education & 224 & 221 & 208 & 264 & * & * \\
\hline 1-7 Years & 143 & 145 & 140 & 129 & * & 149 \\
\hline Completed Primary & 195 & 196 & 211 & 182 & * & * \\
\hline 9-11 Years & 192 & 181 & 230 & 184 & 117 & 154 \\
\hline Completed High School & 162 & 147 & 206 & 167 & 102 & 124 \\
\hline 1-3 Years College & 131 & 120 & 169 & 147 & 100 & 94 \\
\hline Completed College & 103 & 98 & 132 & 131 & * & 98 \\
\hline Graduate Education & 100 & 100 & 100 & 100 & * & 100 \\
\hline NEONATAL MORTALITY RATE & & & & & & \\
\hline Total & 544.3 & 441.7 & 927.4 & 1072.5 & 548.3 & 358.0 \\
\hline No Formal Education & 690.3 & 691.6 & 686.4 & 1144.8 & * & * \\
\hline 1-7 Years & 435.3 & 429.4 & 507.8 & 734.5 & * & 448.2 \\
\hline Completed Primary & 532.2 & 520.0 & 656.4 & 850.3 & * & * \\
\hline 9-11 Years & 513.4 & 467.6 & 758.2 & 842.4 & 384.0 & 487.5 \\
\hline Completed High School & 480.8 & 416.4 & 767.2 & 867.1 & 409.8 & 356.9 \\
\hline 1-3 Years College & 420.8 & 371.8 & 677.6 & 832.8 & 446.3 & 269.5 \\
\hline Completed College & 352.2 & 324.1 & 566.2 & 816.3 & * & 294.7 \\
\hline Graduate Education & 340.8 & 332.8 & 397.4 & 613.3 & * & 280.8 \\
\hline Not stated & 969.6 & 727.1 & 1271.2 & 1327.1 & 774.0 & 617.7 \\
\hline MORTALITY RATIOS & & & & & & \\
\hline Total & 160 & 136 & 233 & 175 & 123 & 128 \\
\hline No Formal Education & 203 & 213 & 173 & 187 & * & * \\
\hline 1-7 Years & 128 & 132 & 128 & 120 & * & 160 \\
\hline Completed Primary & 156 & 160 & 165 & 139 & * & * \\
\hline 9-11 Years & 151 & 144 & 191 & 137 & 86 & 174 \\
\hline Completed High School & 141 & 128 & 193 & 141 & 92 & 127 \\
\hline 1-3 Years College & 123 & 115 & 170 & 136 & 100 & 96 \\
\hline Completed College & 103 & 100 & 142 & 133 & * & 105 \\
\hline Graduate Education & 100 & 103 & 100 & 100 & * & 100 \\
\hline
\end{tabular}


Table 8 (cont.)

\begin{tabular}{|c|c|c|c|c|c|c|}
\hline $\begin{array}{l}\text { Education } \\
\text { of Father }\end{array}$ & $\begin{array}{l}\text { All } \\
\text { Races }\end{array}$ & ace of & $\begin{array}{c}\text { other } \\
\text { All } \\
\text { other }\end{array}$ & Black & $\begin{array}{l}\text { American } \\
\text { Indian }\end{array}$ & $\begin{array}{l}\text { Asian \& } \\
\text { Pacific } \\
\text { Islander }\end{array}$ \\
\hline POSTNEONATAL MORTALITY & & & & & & \\
\hline Total & 318.7 & 263.7 & 524.0 & 585.8 & 584.4 & 222.7 \\
\hline No Formal Education & 391.2 & 341.5 & 549.1 & 1010.1 & * & * \\
\hline $1-7$ Years & 255.1 & 249.4 & 325.0 & 314.8 & * & 272.1 \\
\hline Completed Primary & 412.9 & 394.7 & 598.5 & 637.7 & * & * \\
\hline 9-11 Years & 413.9 & 377.7 & 607.9 & 656.8 & 633.5 & 257.3 \\
\hline Completed High School & 304.3 & 269.6 & 458.9 & 498.2 & 476.7 & 242.7 \\
\hline 1-3 Years College & 213.7 & 191.8 & 328.2 & 369.5 & 422.8 & 185.3 \\
\hline Completed College & 145.6 & 135.9 & 219.4 & 254.0 & * & 180.1 \\
\hline Graduate Education & 142.7 & 134.9 & 197.5 & 202.1 & * & 202.2 \\
\hline Not stated & 552.6 & 437.3 & 696.0 & 717.0 & 698.0 & 311.9 \\
\hline MORTALITY RATIOS & & & & & & \\
\hline Total & 223 & 195 & 265 & 290 & 138 & 110 \\
\hline No Formal Education & 274 & 253 & 278 & 500 & * & * \\
\hline 1-7 Years & 179 & 185 & 165 & 156 & * & 135 \\
\hline Completed Primary & 289 & 293 & 303 & 316 & * & * \\
\hline 9-11 Years & 290 & 280 & 308 & 325 & 150 & 127 \\
\hline Completed High School & 213 & 200 & 232 & 246 & 113 & 120 \\
\hline $1-3$ Years College & 150 & 142 & 166 & 183 & 100 & 92 \\
\hline Completed College & 102 & 101 & 111 & 126 & * & 89 \\
\hline Graduate Education & 100 & 100 & 100 & 100 & * & 100 \\
\hline
\end{tabular}


Table 9. Mortality Ratios. Highest to Lowest Social Classes. United States, $1895-1966$.

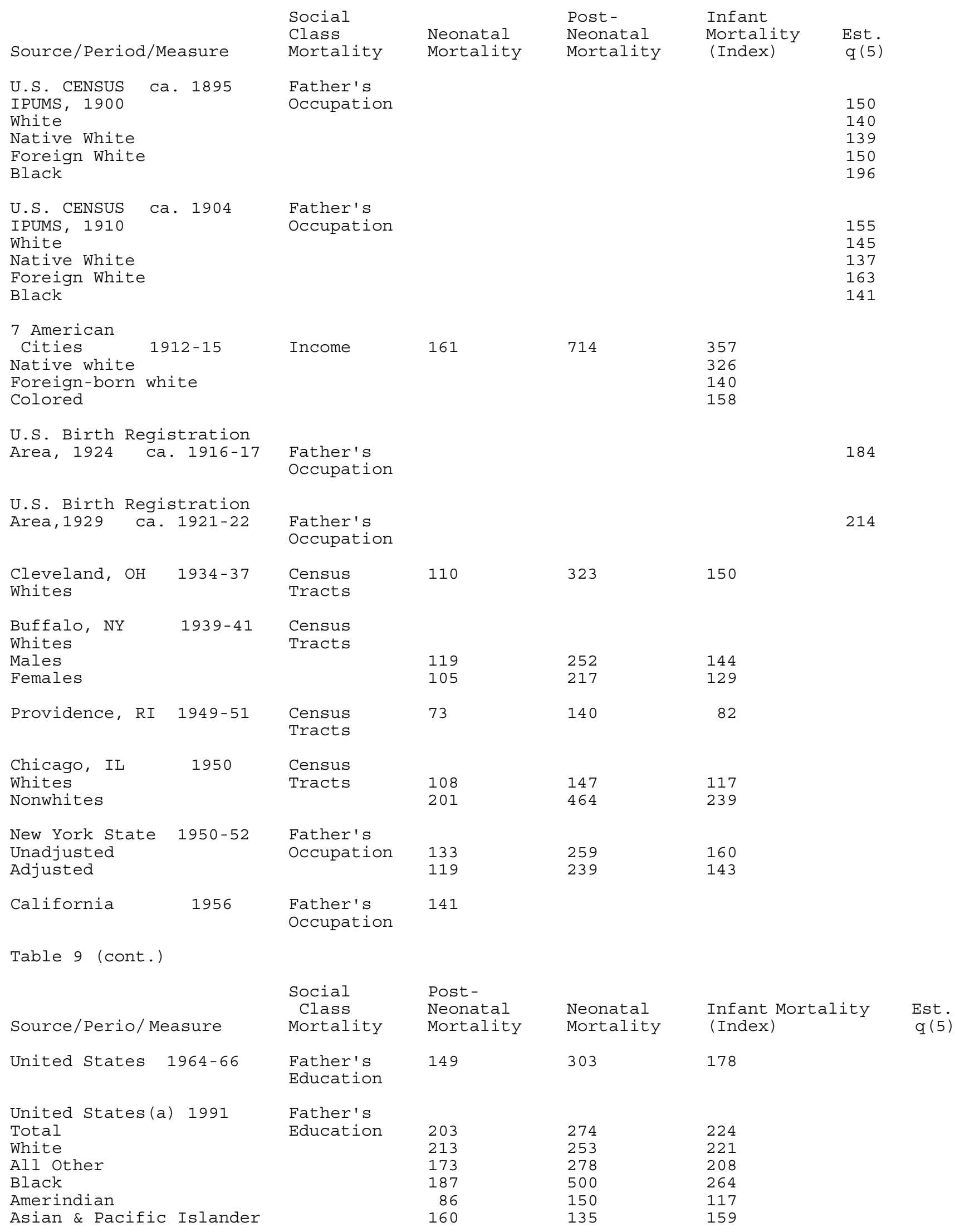




\begin{tabular}{|c|c|c|c|c|}
\hline United States (b) 1991 & Father's & & & \\
\hline Total & Education & 156 & 289 & 195 \\
\hline White & & 160 & 293 & 196 \\
\hline All Other & & 165 & 303 & 211 \\
\hline Black & & 139 & 316 & 182 \\
\hline Amerindian & & 86 & 150 & 117 \\
\hline Asian \& Pacific Islander & & 160 & 135 & 149 \\
\hline
\end{tabular}

(a) Ratio using husbands with no formal education

(b) Ratio using husbands with completed primary education.

Source: Tables 1-8. Antonovsky and Bernstein [1977]. 